\title{
切り欠きのある円柱の抵抗低減 （ストローハル数と表面流れ）
}

\section{Drag Reduction of a Circular Cylinder with Grooves (Strouhal Number and Surface Flow Pattern)}

\section{正五十嵐 保（防衛大） 正 横井 嘉文（防衛大） O学 平尾 恵子（防衛大）}

Tamotsu IGARASHI, National Defense Academy, 1-10-20 Hashirimizu Yokosuka, 239-8686

Yoshifumi YOKOI, National Defense Academy, 1-10-20 Hashirimizu Yokosuka, 239-8686

Keiko HIRAO, National Defense Academy, 1-10-20 Hashirimizu Yokosuka, 239-8686

Key Words: Boundary Layer, Transition, Flow Visualization, Flow Control, Strouhal number

\section{1.まえがき}

鈍い物体に働く抗力の軽減に関し多くの方法で研究が行 われてきた，そのうちの一つに，強制的に境界層をはく離・ 再付着させ，乱流遷移を起こさせる方法がある。例えば，円 柱 ${ }^{(1)}$ の壁面にトリッピング・ワイヤを設置する方法，平板 ${ }^{(2)}$ や円板 ${ }^{(3)}$ の端部に切り欠きを設ける方法がある. 本報では円 柱の前面に切り欠きを設けることにより境界層の遷移・乱流 はく離を起こさせ，抗力の半減が期待された。また，迎え角 の影響も調べた。

\section{2. 実験装置および方法}

図 1 に切り欠き円柱の断面形状と座標系を示寸. 円柱直径 は $d=50 \mathrm{~mm}$ で, 円周上の切り欠き部位置, $\theta_{f^{-}} \theta_{r}$ は $50-70^{\circ}$,

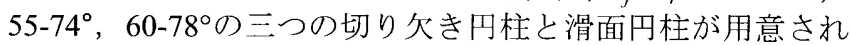
た. 一様流速度は $U=3 \sim 30 \mathrm{~m} / \mathrm{s}$, この範囲内で主流乱れは ほぼ $0.4 \%$ で，実験レイノルズ数は $R e=10^{4} \sim 10^{5}$ の範囲であ る.また，迎え角 $\alpha$ の影響を調べた。 円柱後流の速度変動 のパワースペクトルから渦放出数を測定し，ストローハル数 を求めた. さらに, 油膜法により円柱表面流れを可視化し, 境界層の遷移と乱流はく離位置を測定した.

\section{3. 実験結果および考察}

3-1 ストローハル数 図 2 にモデル 3(60-78 $)$ の切り欠き円 柱のストローハル数を示す. 図 2 (a)の迎え角 $\alpha=0,10^{\circ}$ で は $R e>3 \times 10^{4}$ でストローハル数 $S$ は 0.25 をこえ, Re $>5 \times 10^{4}$ では $S=0.28 \sim 0.29$ のほぼ一定となっている. 乱流はく離が 起こっていることを示唆している. 図 2 (b) は $R e=6.3 \times 10^{4}$ に おける迎え角 $\alpha$ の影響を示し， $\alpha=20^{\circ}$ で $S$ は不連続的に減少 し，円柱上側では切り欠き部の上部側で層流はく離している。 3-2 円柱表面の油膜模様 円柱表面の油膜模様によれば, はく離した流れが切り久き部後部に再付着し, 下流の $\theta_{s}=92^{\circ}$ で乱流はく離している.なお，他の二つのモデルでも同様で ある.また，迎え角 $\alpha$ のある場合も上例は $\alpha+\theta_{f}<80^{\circ}$ では乱

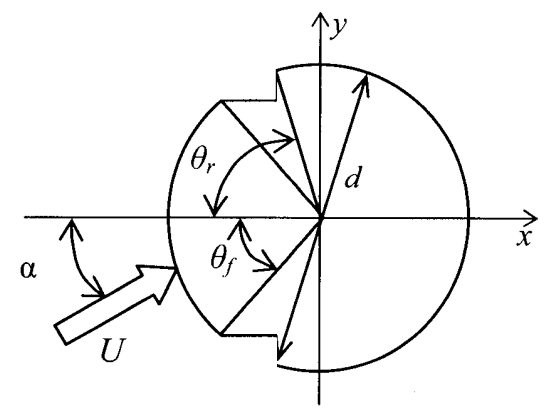

Fig. 1 Coordinate system and symbols
流はく離している.下例は $\alpha<30^{\circ}$ で乱流はく離している. 3-3 抗力軽減の予測 五十嵐(1)によれば，トリッピング・ワ イヤ付き円柱の抗力係数 $C_{D}$ はストローハル数 $S$ とフローパ ターンに依らず，次の関係にある.

$$
S=0.22 / C_{D}^{0.514}
$$

切り久き円柱では $S=0.28 \sim 0.30$ であるから, $C_{D}=0.63 \sim$ 0.55 となる. 40 から $50 \%$ の抗力軽減が期待される. なお, 滑面円柱では $S=0.20$ で $C_{D}=1.20$ である.

\section{4. 結論}

切り欠きを有する円柱は境界層が遷移し乱流はく離する. ストローハル数は 0.30 まで増加する. 円柱の抗力が半減する ことが期待される.

\section{引用文献}

(1) 五十嵐保, 機論, 52-473, B (1986), 358-366.

(2) 五十嵐ら, 日本流体力学会年会, (2005) 88 .

(3) 五十嵐ら, 機講論, 05-32, (2005) 105.

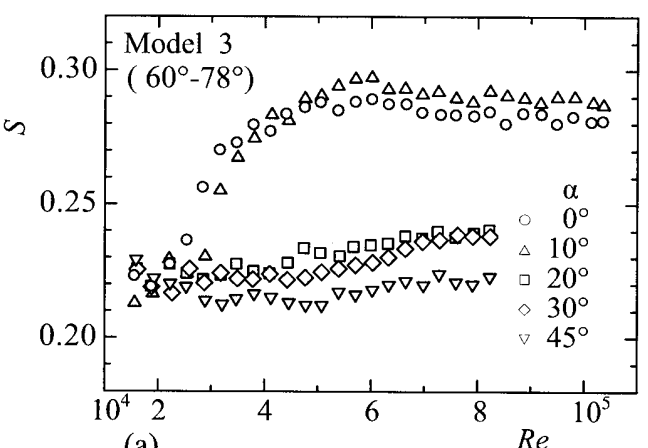

(a)

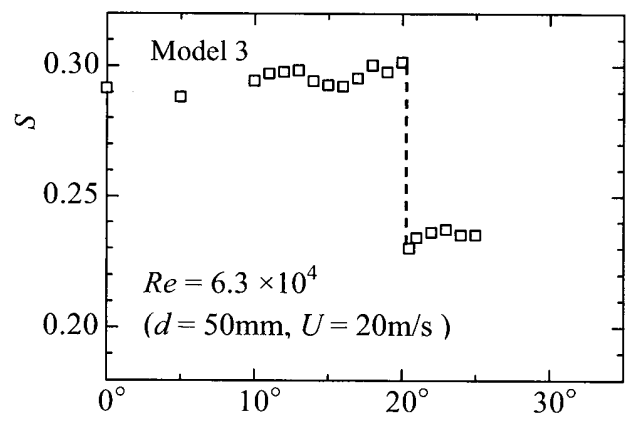

(b)

Fig. 2 Strouhal number vs. Reynolds number and discontinuous change of Strouhal number with attack angle 